\title{
Kirjaston verkkokäytön mittaamista kehittämässä
}

\author{
Liisa Tiittanen
}

Tilastot ovat yksi tapa kertoa siitä, millainen kirjasto on: mitä palveluita tai aineistoja kirjasto tarjoaa sekä millä tavalla ja kuinka paljon kirjastoa käytetään. Nopea digitalisoituminen on muuttanut kirjaston käyttötapoja - pysyykö tilastointi mukana? Kirjaston verkkokäyttöön liittyviä tilastointikysymyksiä käsiteltiin Turun ammattikorkeakoulun kirjasto- ja tietopalveluiden toimeksiannosta tehdyssä ylemmän ammattikorkeakoulututkinnon kehittämistyössä.

\section{YAMK-opinnäytetyöllä apua kehittämiseen}

Turun ammattikorkeakoulun kirjasto- ja tietopalveluissa on jo useamman vuoden ajan pyritty kehittämään kirjaston verkkokäyttöön liittyvien tilastolukujen keräämistä. Luonteva aihe kirjaston toimeksiannosta tehdylle, Turun AMK:n kirjasto- ja tietopalvelun koulutuksen YAMK-opiskelijan kehittämistyölle oli kirjaston verkkokäytön mittaamisen kehittäminen.

Ylempään ammattikorkeakoulututkintoon sisältyy tutkimuksellisena kehittämistyönä tehtävä opinnäytetyö. Turun AMK:n tutkintosäännössä (2017) YAMK-kehittämistyön tavoitteeksi on määritelty" kehittää kykyä soveltaa tutkimustietoa ja-menetelmiä työelämän ongelmien erittelyyn ja ratkaisemiseen sekä osoittaa valmiutta itsenäiseen vaativaan asiantuntijatyöhön." Kehittämistyön suunnitteluprosessi saattaa alkaa jo opiskelijavalinnan ennakkotehtävissä, mikä sitouttaa sekä tulevan opiskelijan että toimeksiantajan kehittämistyöhön. Koska YAMK-opiskelijoilla on ovat usein jo valmiiksi työelämässä, hyötyvät työelämä sekä opiskelijan työnantaja kehittämistyön tulosten lisäksi työntekijän osaamisen kehittymisestä. YAMK-kehittämistyöt tehdään usein myös tiiviissä yhteistyössä oman työorganisaation kanssa: Turun AMK:n kirjastossa opiskelijan taustatukena toimi elektronisten aineistojen tilastointia tekevä työryhmä.
Kehittämistyön tavoitteena oli edistää kirjaston digitaalisten palvelujen esilletuomista tilastojen valossa: mitä pitäisi tilastoida, jotta kirjaston käyttö verkossa tulisi tilastojen avulla näkyviin ja miten pystymme kertomaan siitä, miten kirjastoa käytetään fyysisten kirjastokäyntien vähentyessä. Lisäksi kehittämistyöllä pyrittiin muodostamaan kokonaiskuva monitahoisesta aiheesta sekä lisäämään osaamista elektronisten aineistojen sekä verkkokäytön tilastoinnista.

Kehittämistyön tekeminen vaiheistettiin neljään osaan, joista ensimmäisessä vaiheessa perehdyttiin aiheeseen liittyviin käsitteisiin ja tutkimuksiin, toisessa vaiheessa selvitettiin kehittämistarpeet Turun AMK:n kirjastossa ja kolmannessa vaiheessa selvitettiin, millaisia verkkokäytön mittareita on olemassa ja miten verkkokäyttöä mitataan valikoiduissa kansallisissa tilastoissa. Neljännessä vaiheessa muodostettiin johtopäätökset ja niiden avulla suositukset Turun AMK:n kirjastolle.

\section{Verkkokäytön mittaamisen merkityksestä}

Korkeakoulukirjastojen kokoelmien digitalisoituminen on nähtävissä Suomen tieteellisten kirjastojen yhteistilastosta elektronisten kirja- ja kausijulkaisunimekkeiden määrän merkittävänä kasvuna viimeisen kymmenen vuoden aikana. Samaan aikaan fyysisten kirjastokäyntien mää- 
rä on vähentynyt.

Fyysisten kirjastokäyntien vähetessä saatetaan ajatella, että kirjaston käyttö on vähentynyt, minkä takia kirjastoon ja sen tarjoamiin palveluihin ei enää investoida. Käyttäjät eivät välttämättä edes tiedä käyttävänsä kirjaston tarjoamia palveluja ollessaan elektronisessa ympäristössä, mikä saattaa vaikuttaa esimerkiksi käyttäjäkyselyillä saatuihin vastauksiin, joilla tutkitaan kirjastopalveluiden käyttöä ja merkitystä kirjaston asiakkaille. (Price \& Fleming-May 2011, 197-198.)

Kirjaston kokoelmien ja palveluiden digitalisoituminen aiheuttaa siis haasteita, jotka liittyvät kirjaston rahoituksen ja kärjistettynä jopa koko olemassaolon turvaamiseen. Bertot ja McClure $(2001,78-80)$ totesivat jo 2000-luvun alussa, että verkkosivujen käytön, verkon kautta tulleiden kysymysten sekä aineistolatausten tilastointi on yhtä tärkeää tai jopa tärkeämpää kuin perinteisten tilastolukujen, kuten esimerkiksi lainauslukujen tilastointi. Stewart $(2011,174)$ väittää kirjastojen kyvyn mitata elektronisten aineistojen käyttöä olevan jopa yksi tärkeimmistä kirjastojen johtamiseen liittyvistä haasteista akateemisissa kirjastoissa.

\section{Verkkokäytön mittaamisen haasteita}

Kirjastokontekstissa verkkopalveluiden käytön mittaamiseen liittyviä ongelmia voidaan

tarkastella ainakin kolmesta eri näkökulmasta: millaisia haasteita verkkopalveluiden käytön mittaaminen aiheuttaa, mitä ongelmia kirjaston hankkimien elektronisten tietoaineistojen tilastodatan keräämisessä ja käsittelyssä on sekä miten kansalliset tilastot kuvaavat kirjastojen digitalisoitunutta toimintaympäristöä. Esimerkiksi Heikkinen ym. $(2012,15)$ ovat tunnistaneet Suomen tieteellisten kirjastojen yhteistilaston ongelmaksi kirjaston virtuaalikäytön kokonaisuuden näkymisen yhteistilastossa todellisuutta niukempana.

Kirjaston hankkimien elektronisten tietoaineistojen tilastodatan keräämisen ongelmat ovat herättäneet paljon kansainvälistä keskustelua siitä saakka, kun elektroniset aineistot tulivat osaksi kirjastojen kokoelmia. Asian käsittely lisääntyi erityisesti vuosituhannen vaihteessa, jolloin mm. Luther (2001) selvitti elektronisten aineistojen käytön tilastoinnin haasteita sekä kirjastojen että aineistonvälittäjien kannalta ja totesi elektronisen aineistojen käytön tilastoinnin ongelmiksi mm. eri välittäjiltä saatujen tilastotietojen keräämisen ja esittämisen standardisoinnin puutteet sekä saatujen tilastotietojen tulkinnan haasteet. Samankaltaisia ongelmia on tuotu esiin myös myöhemmin lukuisilla tutkimuksilla tai muilla havainnoilla (ks. esim. Blecic ym. 2001; Peters 2002; Stemper \& Jaguszewski 2003; Hahn \& Faulkner 2002; Coombs 2005; Nagra 2009; Conyers ym. 2017).

Myös elektronisten aineistojen käytön teknisessä ympäristössä on seikkoja, jotka aiheuttavat haasteita tai vaikuttavat käytöstä saataviin lukuihin, mm. metahakumahdollisuudet, eri palveluiden uloskirjautumisaikojen vaihtelut, erilaiset alustat ja erilaiset kokotekstiformaatit (Nagra 2009, 29).

\section{Miten verkkokäyttöä voidaan mitata?}

Kehittämistyön yhtenä tavoitteena oli kartoittaa, miten verkkokäyttöä voidaan mitata. Verkkokäytön mittaamista on kehitetty erityisesti 2000-luvun alussa standardoinnin lisäksi erilaisissa tutkimuksissa ja kirjastoalan sekä standardointijärjestöjen ohjeistuksissa ja projekteissa. Verkkokäytön mittareita käytiin läpi tutustumalla sekä SFS-ISO 2789:2015 -tilastostandardiin että valittujen kirjaston verkkokäytön mittaamista kehittäneiden hankkeiden raportteihin tai verkkosivuihin: International Coalition of Library Consortia ICOLC:n ohjeistukseen, Euroopan komission EQUINOX-hankkeeseen, Association of Research Libraries (ARL) -yhdistyksen E-metrics-hankkeeseen sekä standardointia edistävään Project COUNTER -hankkeeseen.

Tilastostandardin lisäksi COUNTER on ainoa mittaristo, jota kehitetään edelleen vastaamaan 
muuttuvia tietoaineistoja ja kirjastojen tarpeita. COUNTERissa kuitenkin huomioidaan ainoastaan elektronisten tietoaineistojen mittaaminen, ei siis kaikkia kirjaston tarjoamia verkkopalveluita. Tämän vuoksi myös muiden hankkeiden arviointi oli tarkoituksenmukaista.

Analyysikohteiden valinnan jälkeen standardista, hankkeiden raporteista ja verkkosivuista poimittiin kirjoittajan tulkinnan perusteella ne asiat, joilla voidaan mitata kirjaston käyttäjien toimintaa verkossa. Tällä tavoin löydettiin yhdeksän erilaista mittaamisen kohdetta. Löydettyjen kohteiden esiintymistä tarkasteltiin tämän jälkeen valituissa kansallisissa tilastoissa, koska toinen kehittämistyön tavoite oli selvittää, miten verkkokäyttö näkyy Suomen yleisten kirjastojen tilastoissa sekä kansallisissa korkeakoulu- tai tutkimuskirjastojen tilastoissa.

\section{Verkkokäyttö kansallisissa tilastoissa}

Kehittämistyössä kartoitettiin, onko kansallisissa tilastoissa sellaisia verkkokäyttöä kuvaavia asioita, joita Suomen tieteellisten kirjastojen yhteistilastoon ei kerätä ja joita olisi ehkä syytä kerätä paikallisesti yhteistilastoon toimitettavien lukujen lisäksi. Lisäksi kehittämistyössä haluttiin luoda katsaus siihen, mitä tilastot ylipäätään kertovat kirjaston verkkokäytöstä, koska kansalliset tilastot toimivat eräänlaisena verkkokäytön mittaristona kansallisella tasolla. Vertailukohteiksi valittiin Suomen tieteellisten kirjastojen yhteistilaston lisäksi Suomen yleisten kirjastojen tilastot, Ruotsin kansalliset eri kirjastosektoreiden yhdistetyt tilastot sekä Kanadan ja Norjan korkeakoulu- ja tutkimuskirjastojen tilastot.

Vaikka vertailun kohteena olleet kansalliset tilastot perustuvat samaan standardiin, on niiden tapa esittää tietoa kirjaston verkkokäytöstä keskenään erilaista. Esitys- ja raportointitavan lisäksi eroja on siinä, mikä taho kansallisia tilastoja ylläpitää ja minkälaiset kirjastot raportoivat tilastolukujaan samassa tilastossa. Kirjaston verkkokäytön mittaamisen kohteiden esiintymistä tar- kasteltaessa havaittiin, että Suomen tieteellisten kirjastojen yhteistilastoon tilastoidaan yhdeksästä löydetystä mittaamisen kohteesta kuutta ainakin osittain. Muissa vertailun kohteena olleissa tilastoissa verkkokäytön tilastointi ei ollut yhtä kattavaa, kun verkkokäyttöä arvioidaan niillä mittaamisen kohteilla, joita valituista mittaristoista löydettiin. Mittarien esiintymisen arviointi ei kuitenkaan ole aivan yksiselitteistä, koska tilastot ovat hyvin erilaisia siitä huolimatta, että niihin kerätään tietoa saman standardin mukaisesti ja toisaalta tilastoista löytyy myös sellaisia verkkokäyttöä kuvaavia kohtia, joita ei löytynyt analysoinnin kohteena olevista mittaristoista.

\section{Kehittämistarpeet esille}

Vaikka Suomen tieteellisten kirjastojen yhteistilaston tapa kuvata kirjaston verkkokäyttöä on kattava suhteessa löydettyihin mittaamisen kohteisiin, saatiin Turun AMK:n kirjastossa tehtyjen asiantuntijahaastatteluiden avulla selville, että yhteistilastoon kerätyt luvut eivät kata kaikkea kirjaston verkkokäyttöä. Suomen tieteellisten kirjastojen yhteistilastoon tallennettavista luvuista jää puuttumaan kirjaston käyttäjälle annettava asiakaspalvelu ja ohjaus verkossa, mikä on merkittävä osa monen korkeakoulukirjaston toimintaa. Yhteistilastoon toimitettavia lukuja ei voida myöskään käyttää sellaisenaan silloin, kun kirjasto esittelee toimintaansa kirjaston ulkopuolella esimerkiksi omille sidosryhmilleen tai toiminnan rahoittajille $\mathrm{mm}$. tilastoinnin yksityiskohtaisuuden ja aineistojen käyttötilastojen aineistotyyppikeskeisyyden vuoksi.

Haastatteluissa tuli esille, että muita haasteita verkkokäytön tilastoinnissa aiheuttavat $\mathrm{mm}$. tietoaineistojen käytöstä saatavien tilastojen käsittely, tulkinta ja vertailtavuus. Edelleenkään kaikilta elektronisten tietoaineistojen välittäjältä tai kustantajalta ei saada käyttötilastoja. Myös tilastojen kerääminen Suomen tieteellisten kirjastojen yhteistilastoon koettiin työlääksi. 


\section{Kehittämisehdotuksia kirjaston verkkokäytön esilletuomiseksi}

Koska Suomen tieteellisten kirjastojen yhteistilaston avulla saattaa olla vaikea saada kuvaa siitä, miten kirjastoa käytetään verkossa, tulisi lukuja kiteyttää ja tiivistää helpommin ymmärrettävään muotoon silloin, kun niitä käytetään kirjaston toimintaa kuvaavina mittareina, erityisesti kirjaston ulkopuolella.

Kehittämistyössä ehdotettiin, että Turun AMK:n kirjasto- ja tietopalveluiden olisi hyvä jatkossa tuoda esille kirjaston verkkokäyttöä seuraavilla mittareilla:

- Elektronisten aineistojen käyttökerrat (lataukset tai katsotut tietueet tai tiedonhaut kaikista elektronisista aineistoista yhteensä) yhtä Turun AMK:n yhteisön jäsentä kohden vuodessa, jolloin mitataan yhden Turun AMK:n yhteisön jäsenen tekemiä aineistolatauksia vuodessa, mukaan lukien Theseus-julkaisuarkistosta tehdyt Turun AMK:n aineistojen lataukset. Indikaattorilla saadaan havainnollistettua Turun AMK:ssa tärkeimmäksi koettua elektronisten aineistojen käytöstä kertovaa asiaa ymmärrettävässä mittakaavassa. Lisäksi indikaattorissa otetaan huomioon mahdolliset muutokset Turun AMK:n yhteisön jäsenmäärässä, koska jäsenmäärän muutos vaikuttaa käytön kokonaismäärään. Koska kaikista kirjaston kokoelmiin kuuluvista tietoaineistoista, erityisesti bibliografisista tietokannoista sekä hakuteos- ja sanakirjatietokannoista, ei saada kerättyä katsottuja tietueita, tulisi lukuun sisällyttää tehdyt tiedonhaut näistä aineistoista, jotta indikaattori kuvaisi tietoaineistojen käyttöä kattavammin.

- Verkkosivuille ja Finna-hakupalveluun tehdyt käynnit vuodessa, jolloin mitataan Turun AMK:n kirjasto- ja tietopalveluiden internetsivukäyntejä, intranetsivukäyntejä, LibGuides-oppaisiin tehtyjä käyntejä sekä Finna-hakupalveluun tehtyjä käyntejä vuo- dessa. Tällä indikaattorilla voidaan tuoda esille kirjaston omatoimisen käytön verkossa mahdollistavien verkkopalvelujen ja ohjauspalvelujen merkitystä kirjaston käytön kokonaisuudessa.

\section{- Verkossa tehty asiakaspalvelu ja ohjaus} vuodessa, jolloin mitataan sähköpostitse tai tulevaisuudessa mahdollisen chat-palvelun kautta tehtyjen asiakasyhteydenottojen määrääyhteydenoton aiheesta riippumatta. Tällä indikaattorilla saadaan kuvattua sitä kirjaston käyttötapaa, joka jää tällä hetkellä Tieteellisten kirjastojen yhteistilastossa näkymättömiin.

Suomen tieteellisten kirjastojen yhteistilastoon on vastikään otettu mukaan Finnan käytöstä kertovia lukuja, mikä osaltaan on edistänyt kirjaston verkkokäytön mittaamista kansallisella tasolla. Kirjastojen asiakkailleen tarjoamat verkkopalvelut lisääntyvät ja monimuotoistuvat kuitenkin jatkuvasti, minkä vuoksi verkkopalvelujen mittaamisen kehittämistä tulee edelleen jatkaa myös kansallisella tasolla vastaamaan uusia tietoympäristöjä ja aineistoja.

Verkkokäytöstä saatuja tilastolukuja on arvioitava kriittisesti erityisesti silloin, kun tarkastellaan tilastoja kansallisella tasolla ja verrataan eri kirjastojen tilastoimia käyttölukuja: verkkokäytöstä kertovien lukujen taustalla on useita erilaisia mittaamistapoja, erilaisia määritelmiä sekä käyttöä, jota ei saada tilastojen puuttuessa ollenkaan näkyviin. Tärkeintä kuitenkin lienee, että kirjastot tuovat verkkokäyttöä tavalla tai toisella esille siten, että tämän voimakkaasti lisääntyvä tapa käyttää kirjastoa ei jäisi tilastoja tarkasteltaessa ns. perinteisten tilastolukujen varjoon. Edelleen tarvitaan myös keskustelua sekä kansainvälisellä että kansallisella tasolla niistä haasteista, joita kirjaston palveluiden esilletuominen tilastojen valossa aiheuttaa.

Turun AMK:n kirjasto on pyrkinyt kehittämään kirjaston verkkokäytön mittaamista pitkään: kirjasto on verkkokäyttöä esille tuodessaan hyödyntänyt itse rakentamaansa virtuaalikäyn- 
titilastoa, jossa tuodaan verkkopalveluiden käytön kokonaisuutta esille. Nyt kirjastolla on käytössään kehittämistyössä esitellyt johtopäätökset, joiden avulla kirjaston verkkokäytön näkyvyyttä voidaan kehittää edelleen.

Kehittämistyö on luettavissa Theseuksessa http:// urn.fi/URN:NBN:fi:amk-2017112117622

Tiittanen, L. 2017. Kirjaston verkkokäytön mittaamisen kehittäminen. YAMK-opinnäytetyö. Kirjasto- ja tietopalvelun koulutus. Turku: Turun ammattikorkeakoulu.

\section{Tietoa kirjoittajasta:}

\author{
Liisa Tiittanen \\ Informaatikko \\ Turun ammattikorkeakoulun \\ kirjasto- ja tietopalvelut \\ liisa.tiittanen@turkuamk.fi
}

\section{Lähteet:}

Bertot, J. C. \& McClure, C. 2001. Developing national data collection models for public library network statistics and performance measures: Project update. Teoksessa Stein J.; Kyrillidou, M. \& Davis, D. (toim.) Proceedings of the 4 th Northumbria International Conference on performance measurements in libraries and information services. Pittsburgh, PA, August 2001, 77 - 85. Viitattu 28.3.2017 https://www.libqual.org/documents/admin/4np_secure.pdf.

Blecic, D. D.; Fiscella, J. B. \& Wiberley, S. E. Jr. 2001. The measurement of use of web-based information resources: an early look at vendorsupplied data. College \& Research libraries. Vol. 62, No. 5, September, 434 - 453. Saatavilla myös https://doi.org/10.5860/ crl.62.5.434.

Conyers, A.; Lambert, J.; Wong, L. Jones, H.; Bamkin, M. \& Dalton, P. 2017. E-book usage: counting the challenges and opportunities. Insights. 30(2), 23 30. Viitattu 13.7.2017 http://doi.org/10.1629/uksg.370.

Coombs, K. A. 2005. Lessons learned from analyzing library database usage data. Library Hi Tech. Vol. 23, No 4, 598 - 609.
Hahn, K. L. \& Faulkner, L. A. 2002. Evaluative usage-based metrics for the selection of e-journals. College \& Research Libraries. Vol 63, no 3, 215 - 227. Saatavilla myös https://doi.org/10.5860/crl.63.3.215.

Heikkinen, R.; Laitinen, M.; Lappalainen, V.; Parikka, S.; Rasinkangas, P.; Saarti, J.; Söderholm, M.; Suikkanen, E. \& Vainikka, E. 2012. Kirjastojen toiminnan arviointi: yhteisten mittareiden toimivuus ja kehittäminen. Signum. Vol. 45, No 4, 13 - 19. Saatavilla myös https://journal.fi/signum/article/view/6962.

Luther, J. 2001. White paper on electronic journal usage statistics. Council on Library and

Information Resources. Viitattu 26.3.2017 https:// www.clir.org/pubs/reports/pub94.

Nagra, K. A. 2009. The evaluation of use of electronic resources and services in academic libraries: a study of e-metrics and related methods for measurement and assessment. Journal of The Library Administration \& Management Section. 6(1), 28 - 41.

Peters, T. A. 2002. What's the use? The value of e-resource usage statistics. New Library World. Vol 103, No 1172/1173, 39 - 47.

Price, A. (reporter) \& Fleming-May, R. (presenter). 2011. Download or outcomes. Measuring and communicating the contributions of library resources to faculty and student success. The Serials Librarian. Vol. 61, No 2, 196 - 199.

Stemper, J. A. \& Jaguszewski, J. M. 2003. Usage statistics for electronic journals: an analysis of local and vendor counts. Collection Management. Vol. 28, No $4,3-22$.

Stewart, C. 2011. Keeping track of it all: the challenge of measuring digital resource usage. The Journal of Academic Librarianship. Vol. 37, No 2, 174 - 176.

Turun ammattikorkeakoulu. 2017. Turun ammattikorkeakoulun tutkintosääntö. Viitattu 25.3.2018 https:// www.turkuamk.fi/fi/tutkinnot-ja-opiskelu/opiskeluturun-amkssa/opiskelu-ammattikorkeakoulussa/ > Tutkintosääntö. 